\title{
KONSEP NILAI WAJAR (FAIR VALUE) \\ DALAM STANDAR AKUNTANSI BERBASIS IFRS DI INDONESIA APA DAN BAGAIMANA?
}

\author{
Heri Sukendar W. \\ Jurusan Akuntansi, Fakultas Ekonomi dan Bisnis, Universitas Bina Nusantara \\ Jl. K.H. Syahdan No. 9, Palmerah, Jakarta Barat 11480 \\ heris1024@yahoo.com
}

\begin{abstract}
This paper is intended to explain the use of the concept of fair value instead of book value. The accounting world in Indonesia during the last few years have made convergency implementation of new accounting standards oriented to the International Financial Reporting Standards (IFRS) issued by International Accounting Standard Boars (IASB). This new accounting standard that emphasizes the concept of fair value compared with book value concept is outdated. The use of the concept of fair value of the difference and it turned out to be a trigger konvergency change the paradigm of the book value of a simpler, but less information is less transparent. The implementation of accounting standards konverjensi done gradually raises serious problems, this can be seen from postponed the application of PSAK 50 \& PSAK 55 in the banking industry. Knowledge and experience of inadequate is a priority of fair value implementation difficulties.
\end{abstract}

Keywords: IFRS, PSAK, fairvalue, historical cost, relevant, reliability, transparant

\begin{abstract}
ABSTRAK
Tulisan ini ditujukan untuk menjelaskan penggunaan konsep nilai wajar sebagai pengganti dari nilai buku. Dunia akuntansi di Indonesia selama beberapa tahun terakhir telah melakukan konverjensi penerapan standar akuntansi yang baru yang berkiblat kepada Internasional Financial Reporting Standard (IFRS) yang dikeluarkan oleh Internasional Accounting Standard Boars (IASB). Standar akuntansi yang baru ini menekankan konsep nilai wajar dibandingkan dengan konsep nilai buku yang sudah usang. Penggunaan konsep nilai wajar yang menjadi pembeda dan pemicu konverjensi ini ternyata harus mengubah paradigma nilai buku yang lebih sederhana, namun kurang memberikan informasi yang kurang transparan..Pelaksanaan konverjensi standar akuntansi yang dilakukan secara bertahap ini menimbulkan masalah yang cukup serius, hal ini dapat dilihat dari ditundanya penerapan PSAK 50 \& PSAK 55 di industry perbankan. Pengetahuan dan pengalaman yang kurang memadai merupakan hal yang utama dari kesulitan implementasi nilai wajar.
\end{abstract}

Kata kunci: IFRS, PSAK, nilai wajar, harga perolehan, relevan, reliabilitas, transparansi 


\section{PENDAHULUAN}

Akuntansi merupakan bahasa bisnis yang disepakati oleh semua pihak sebagai alat dalam mengukur kinerja keuangan suatu organisasi usaha dan dijadikan sebagai dasar dalam pengambilan keputusan bisnis oleh semua pihak terkait (stakeholders), sehingga laporan keuangan yang disajikan haruslah tidak memihak, dapat diandalkan dan tepat waktu. Pelaporan keuangan telah diatur sedemikian rupa sehingga laporan keuangan dapat menyajikan informasi yang benar-benar dapat diandalkan untuk pengambilan keputusan. Namun seiring dengan berjalannya waktu, akuntan menemukan banyak celah dalam pendekatan-pendekatan pelaporan keuangan yang telah ada, untuk melakukan fraud (kecurangan). Hal ini merupakan salah satu sebab munculnya pengaturan akuntansi baru yang principal based yaitu IFRS (International Financial Reporting Standard).

Dalam IFRS dikembangkanlah pendekatan-pendekatan baru dalam pelaporan keuangan untuk meningkatkan transparansi, akuntabilitas, dan keterbandingan laporan keuangan. Misalnya, ditingkatkannya pengungkapan informasi kualitatif transaksi, pengaturan untuk pelaporan keuangan menggunakan principal based, yaitu prinsip yang menekankan kepada professional judgement bukan lagi rule based, dimana akuntan dalam menyusun laporan keuangan berdasarkan prinsip-prinsip yang diatur secara mendetail, serta dihapusnya pos-pos luar biasa, penyajian laporan keuangan diubah untuk mencerminkan sifat laporan keuangan, dan penggunaan pendekatan pengukuran nilai wajar (fair value).

Dengan adanya standar global tersebut memungkinkan keterbandingan dan pertukaran informasi secara universal. Konvergensi IFRS dapat meningkatkan daya informasi dari laporan keuangan perusahaan-perusahaan yang ada di Indonesia. Adopsi standar internasional juga sangat penting dalam rangka stabilitas perekonomian. Manfaat dari program konvergensi IFRS diharapkan akan mengurangi hambatan-hambatan investasi, meningkatkan transparansi perusahaan, mengurangi biaya yang terkait dengan penyusunan laporan keuangan, dan mengurangi cost of capital. Indonesia yang tadinya lebih condong ke standar akuntansi keluaran FASB, sejak tahun 1994 sudah mulai melakukan harmonisasi dan lebih mendekatkan diri ke IFRS.

Sebelum digunakannya International Financial Reporting Standards (IFRS), akuntansi di Indonesia menggunakan historical cost untuk pengukuran transaksinya. Dalam konsep ini, pos-pos laporan keuangan diukur sebesar cost (biaya) pada waktu terjadinya transaksi. Biaya ini kemudian akan menjadi dasar pelaporan besarnya suatu pos untuk periode selanjutnya, selama pos tersebut masih dilaporkan. Keuntungan dari digunakannya pendekatan historical cost ini adalah, besarnya pos laporan keuangan dapat dibuktikan dengan mudah karena berdasarkan transaksi yang telah terjadi. Namun, ketika terjadi penurunan atau peningkatan nilai suatu pos di pasar (bisa jadi karena inflasi atau deflasi, atau karena kelangkaan produk, dan lain sebagainya), pos yang dilaporkan tidak akan mencerminkan nilai yang berubah ini.

Seiring perkembangan zaman, penggunaan historical cost tidak lagi relevan karena kredibilitas dan kegunaan laporan keuangan telah terhambat oleh tantangan yang serius. Dan banyak orang yang berpendapat dan yakin bahwa standard akuntansi yang menggunakan historical cost memainkan peranan penting sebagai penyebab kerusakan perekonomian, hal ini diungkapkan oleh Shanklin, Hunter dan Ehlen (2011), terutama lembaga simpan pinjam tahun 1980an dan masalah perbankan 1990an. Karena pada waktu itu banyak laporan keuangan yang tidak mengungkapkan kerugian segera pada saat terjadi. Sehingga terdapat kesepakatan bahwa standard akuntansi yang ada perlu diperbaiki untuk memastikan bahwa laporan keuangan bermanfaat, relevan, dan terpercaya.

Menurut ketua umum Masyarakat Profesi Penilai Indonesia (MAPPI) Hamid Yusuf yang dikutip dari Majalah Akuntan Indonesia edisi No. 16 tahun ke III, yang pertama kali mengenalkan 
konsep nilai wajar ini adalah Australia, Inggris, dan negara-negara bekas jajahan Inggris. Konsep ini pertama kali digunakan untuk menghitung aset biologis di lingkungan perusahaan perkebunan dan peternakan di Australia dan Inggris. Pertimbangannya aset dan bidang usaha perusahaan-perusahaan tersebut adalah makhluk hidup, seperti tanaman dan ternak, yang terus berkembang dan berbiak. Jika perusahaan-perusahaan tersebut dinilai dengan nilai buku (historical cost), tentu tidak fair karena mercerminkan nilai ekonomi yang tidak sebenarnya. Dari situ kemudian ditemukan konsep penghitungan yang baru dan kemudian dikenal sebagai nilai wajar. Konsep ini kemudian diadopsi ke dalam standar akuntansi internasional dan diberlakukan pertama kali pada 2003 untuk menilai asetaset biologis di sektor pertanian, perkebunan dan peternakan. Sejak saat itulah, semua perusahaanperusahaan publik di Eropa menggunakan nilai wajar untuk menyusun laporan keuangannya.

Di tengah semangat penerapan konsep nilai wajar, muncul tudingan negatif penerapan konsep nilai wajar (fair value) ini, dimana krisis keuangan yang dipicu oleh subprime mortgage pada semester II 2008, nilai wajar sempat dijadikan kambing hitam. Disebutkan bahwa sistem akuntansi atau pelaporan keuangan yang menggunakan nilai wajar dianggap sebagai penyebab terjadinya krisis keuangan tersebut. Tudingan itu dibantah oleh tim yang dibentuk oleh Security Exchange Comisssion (SEC), tim dari Negara-negara dalam G-20, dan tim dari IMF yang melakukan kajian yang sama, hasil penyelidikan menyebutkan bahwa krisis tidak disebabkan oleh laporan keuangan yang menggunakan nilai wajar, melainkan karena adanya pengambilan resiko yang terlalu besar dan kegagalan perbankan atau lembaga-lembaga keuangan di AS dalam mengantisipasi probable credit losses, keraguan atas kualitas aset dan turunnya kepercayaan kreditur maupun investor. Dengan kata lain adanya kesalahan pengelolaan, bukan karena penerapan konsep nilai wajar. Semua pihak terkait termasuk IMF sepakat untuk meneruskan penggunaan konsep nilai wajar dengan penyempurnaan yang berkelanjutan. Indonesia sebagai Negara anggota G-20 lebih memilih menunda konsep nilai wajar dengan pemberlakukan pada tahun 2012 dari rencana semula tahun 2009.

Dalam kondisi pasar uang dan modal global yang semakin dinamis, dan berkembang sangat cepat, akhirnya konsep historical cost dianggap tidak cocok lagi, karena tidak mencerminkan nilai pasar. Sebagai gantinya digunakan konsep fair value. Fair value ditetapkan oleh International Accounting Standard Board (IASB) sebagai dasar untuk mengukur aset. Berubahnya penggunaan konsep biaya perolehan menjadi konsep baru yaitu konsep nilai wajar dalam dunia akuntansi, tentunya akan berpengaruh kepada akuntan perusahaan, akuntan publik dalam penyusunan laporan keuangan perusahaan. Dalam tulisan berikut ini, penulis akan menyampaikan definisi, aplikasi, pro kontra nilai wajar, kelebihan dan keunggulan nilai wajar, dan kontribusi jasa appraisal (penilai) dalam dunia akuntansi.

\section{METODE}

Dalam mengkaji masalah nilai wajar, penulis menggunakan metode penelitian literatur sebagai acuan kajian. Penelitian dengan metode ini merupakan analisis terhadap konsep. Analisis konsep merupakan pembuatan eksistensi dan frekuensi konsep yang biasanya dipresentasikan dalam bentuk kata-kata dalam frasa yang terdapat dalam teks (dalam hal ini berupa literatur). Fokus analisis ini ditujukan pada pengamatan terhadap permasalahan nilai wajar yang merupakan fenomena baru di dunia akuntansi akhir-akhir ini yang dianggap penting dan mendukung tujuan penelitian.

Sebagai tolok ukurnya, penulis menggunakan beberapa acuan pustaka seperti buku IFRS Wiley 2010 yang menjelaskan konsep-konsep dasar pelaporan akuntansi standar internasional, memetakan masalah-masalah yang dihadapi dan menguraikan upaya-upaya untuk mengatasi masalah penghitungannya. Atas dasar buku acuan tersebut yang merupakan konsep akuntansi modern diuraikan definisi, manfaat, pengukuran, pengakuan, pelaporan dan pengungkapan atas penerapan konsep nilai wajar secara sederhana. 


\section{PEMBAHASAN}

Fair value (nilai wajar) telah menggantikan nilai buku yang selama ini sebagai basis yang digunakan dalam pengukuran aset tetap atau pos keuangan lainnya. Nilai wajar ditetapkan oleh International Accounting Standard Board (IASB) sebagai dasar untuk mengukur asset dan liabilitas. Kebutuhan informasi dari suatu kondisi keuangan pada satu entitas sering dilihat dari laporan keuangan entitas tersebut. Kinerja suatu laporan keuangan seharusnya dapat memberikan gambaran atas beberapa indikator kinerja keuangan entitas dimaksud. Pada gilirannya laporan keuangan tersebut akan memberikan gambaran atas kualitas aset dan kewajiban yang dimiliki entitas.

\section{Definisi Nilai Wajar}

Menurut Epstein dan Jermakowicz (2010), nilai wajar didefinisikan sebagai, "the amount for which an asset could be exchanged between knowledgeable, willing parties in an arm's length transaction." Nilai wajar dinilai sebagai konsep yang paling sesuai dan relevan untuk penyusunan laporan keuangan sebuah perusahaan atau entitas bisnis sebab bisa menggambarkan nilai pasar yang sebenarnya terjadi. Nilai wajar ini digunakan untuk mengukur: satu aset, sekelompok aset, satu liabilitas, sekelompok liabilitas, konsiderasi bersih dari satu atau lebih aset dikurangi satu atau lebih liabilitas terkait, satu segmen atau divisi dari sebuah entitas, satu lokasi atau wilayah dari suatu entitas, satu keseluruhan entitas.

Dewan Standar Keuangan Internasional-IFRS telah memberikan statement, bahwa nilai wajar merupakan satu- satunya konsep yang relevan dalam dunia bisnis. Adapun pendapat mereka dalam IFRS-Wiley 2010 adalah: (1) akuntansi nilai wajar dapat meningkatkan transparasi atas informasi yang disampaikan kepada publik; (2) informasi nilai wajar adalah informasi utama dalam keadaan ekonomi saat ini; dan (3) dengan nilai wajar, akan memberikan informasi yang lebih kini pada kreditor dan investor.

\section{Penghitungan/Pengukuran Nilai Wajar Berdasarkan PSAK}

Saat ini nilai wajar dianggap sebagai konsep yang paling sesuai dan relevan untuk penyusunan laporan keuangan sebuah perusahaan atau entitas bisnis sebab bisa menggambarkan nilai pasar yang sebenarnya terjadi pada saat itu. Yang dimaksud dengan pengukuran di atas bukan merupakan pengukuran awal. Untuk pengukuran awal (saat aset diakuisisi atau liabilitas muncul), entitas tetap menggunakan dasar nilai buku atau harga perolehant pada saat terjadinya transaksi. Setelah pengukuran awal (biasa disebut sebagai pengukuran setelah pengukuran awal), yaitu saat pelaporan keuangan (dan untuk pelaporan seterusnya, selama aset masih dikuasai), entitas boleh memilih model cost (berdasar historical cost) atau model revaluasi (berdasar nilai wajar) untuk mengukur pos-pos laporan keuangannya.Dari definisinya, dapat disimpulkan bahwa nilai wajar diukur menggunakan dasar ketika aset (atau liabilitas) dapat ditukar, bukan ketika aset (liabilitas) benar-benar ditukar. Saat ini dari seluruh PSAK yang berlaku di Indonesia terdapat 12 PSAK yang melibatkan nilai wajar , yaitu PSAK No. 10, 13, 16, 22, 23, 24, 30, 48, 50, 55, 58 dan 60.

Menurut Pernyataan Standar Akuntansi Keuangan No. 10 (revisi 2010) tentang pengaruh perubahan kurs valuta asing, nilai wajar di definisikan sebagai istilah yang dipakai untuk mempertukarkan asset atau menyelesaikan liabilitas antara pihak-pihak yang berkeinginan dalam sutau transaksi wajar.

Dalam PSAK 13 (revisi 2008), tentang properti investasi, nilai wajar adalah harga mana properti dipertukarkan antara pihak-pihak yang memiliki pengetahuan memadai dan berkeinginan dalam suatu transaksi yang wajar (arm's length transaction). Acuan terbaik nilai wajar yang 
digunakan adalah berdasarkan harga kini dalam pasar aktif untuk properti serupa dalam lokasi dan dan kondisi serupa. Namun harga ini belum tentu tersedia karena pasar aktif properti belum tentu tersedia. Dalam kondisi tidak tersedianya harga di pasar aktif, maka entitas dapat menentukan nilai wajar dengan mempertimbangkan informasi dari berbagai sumber, di antaranya: (1) harga kini dalam pasar aktif untuk properti serupa dilokasi yang berbeda, kemudian disesuaikan untuk perbedaan lokasi tersebut; (2) harga terakhir properti serupa dalam pasar yang kurang aktif dengan penyesuaian untuk mencerminkan adanya perubahan dalam kondisi ekonomi sejak tanggal transaksi terjadi pada harga tersebut; (3) nilai estimasi arus kas masa depan (metode discounted cash flow) menggunakan tingkat diskonto yang mencerminkan resiko atas ketidak pastian dalam jumlah dan waktu arus kas.

Penghitungan nilai wajar ini dilakukan setiap tanggal neraca, entitas harus menghitung nilai wajar dari properti investasi. Keuntungan atau kerugian dari perubahan nilai wajar atas properti investasi diakui dalam laba-rugi periode berjalan.

Dalam PSAK No, 16 (revisi 2007), penggunaan nilai wajar dalam dilihat dalam pengukuran setelah pengakuan awal, dimana setelah pengakuan awal, maka asset tetap secara berkala diukur nilai wajarnya dengan metode revaluasian. Dalam metode ini nilai revaluasian adalah nilai wajar pada tanggal revaluasi dikurangi akumulasi penyusutan dan akumulasi rugi penurunan nilai yang terjadi setelah tanggal revaluasi. Penetapan nilai wajar dilakukan melalui penilai yang memiliki kualifikasi professional. Untuk penilaian terhadap tanah dan bangunan, biasanya penilai menggunakan bukti pasar. Sedangkan untuk penilaian asset tetap lain seperti pabrik dan peralatan, penilai menentukan sendiri nilai pasar wajarnya. Jika tidak ada pasar yang memperjualbelikan asset tetap serupa, penentuan nilai pasar wajar dapat dilakukan dengan pendekatan penghasilan atau biaya pengganti yang telah disusutkan (depreciated replacement cost approach). Revaluasi asset tetap harus dilakukan menyeluruh dan kenaikan asset tercatat akibat revaluasi langsung dikreditkan ke ekuitas pada bagian selisih penilaian kembali aktiva tetap. Dari sudut perpajakan untuk revaluasi asset tetap adalah dikenakannya PPh final sebesar 10\% atas selisih lebih penilaian kembali aktiva tetap.

Dalam PSAK 22 (revisi 2010) mengenai kombinasi bisnis, teknik penilaian nilai wajar tidak diatur secara tegas, khususnya dalam panduan aplikatif dan penggunaan beberapa teknik penilaian dalam penentuan nilai wajar. PSAK 23 (reformat 2007) tentang pendapatan, nilai wajar dari pendapatan diukur berdasarkan imbalan (umumnya berbentuk kas atau setara kas) yang diterima atau yang dapat diterima. Bila kas yang akan diterima ditangguhkan, nilai wajar imbalan ditentukan dengan pendiskontoan seluruh penerimaan dimasa mendatang dengan menggunakan tingkat bunga tersirat (imputed rate).

PSAK 24 (revisi 2004) tentang imbalan kerja, menetapkan acuan nilai wajar berdasarkan harga pasar, bila harga pasar tidak tersedia maka nilai wajar asset program harus diestimasi. PSAK 30 (revisi 2007) tentang sewa, tidak menjelaskan secara gambling tentang tata cara penentuan nilai wajar. PSAK 48 (revisi 2009) tentang penuruan nilai asset memberikan acuan penentuan nilai wajar melalui beberapa tahapan. PSAK 50 (revisi 2006) dan PSAK 55 (revisi 2006), penentuan nilai wajar dilakukan dengan beberapa tahapan. PSAK 58 (revisi 2009) tentang asset tidak lancar yang dimiliki untuk dijual dan operasi yang dihentikan, tidak mengatur secara spesifik metode penentuan nilai wajar yang harus digunakan.

Dalam PSAK 60, tentang pengungkapan instrumen keuangan, konsep nilai wajar memiliki 3 hierarki dalam mengukur 'ketika aset (liabilitas) dapat ditukar'. Misalnya dengan menggunakan harga kuotasian (quoted process at active markets). Dalam pendekatan pasar ini, nilai wajar diukur berdasarkan harga pasar atau informasi relevan lain yang dihasilkan dari transaksi di pasar. Hal ini termasuk harga aset (liabilitas) sejenis yang ada di pasar, dan metode penilaian lain yang konsisten dengan pendekatan pasar. Urutan yang digunakan jika nilai wajar menggunakan pendekatan pasar adalah, pertama harga pasar aset (liabilitas) pada saat pelaporan, jika tidak terdapat harga pasar aset (liabilitas) maka menggunakan harga pasar aset (liabilitas) sejenis, jika tidak terdapat harga pasar aset 
(liabilitas) sejenis maka menggunakan model yang konsisten dengan pendekatan pasar (contohnya model matrix pricing, dan lain-lain).

Input selain harga kuotasian yang dapat diobservasi baik langsung maupun tidak langsung (no actives market, valuation techniques). Hierarki ini umumnya menggunakan pendekatan penghasilan, dimana digunakan teknik penilaian untuk mengubah nilai masa depan (contohnya aliran kas atau laba) ke nilai kininya terdiskonto (discounted). Pengukuran nilai wajar dalam pendekatan ini menggunakan dasar nilai yang dilihat dari harapan pasar kini atas nilai aset (liabilitas) masa depan. Pendekatan ini termasuk menggunakan nilai kini (present value, option pricing).

Input yang bukan berdasarkan data pasar yang dapat diobservasi (no market equities cost). Pendekatan ini umumnya disebut pendekatan biaya pengganti kini (current replacement cost). Biaya pengganti ini adalah jumlah yang diperlukan untuk menggantikan suatu aset.

Dari 11 PSAK tersebut, konsep nilai wajar dapat diringkas seperti pada Gambar 1.

\begin{tabular}{|c|c|c|c|c|c|c|c|c|c|c|c|}
\hline \multirow[t]{2}{*}{ Kata Kunci } & \multicolumn{10}{|c|}{$\begin{array}{l}\text { Pernyataan Standar Akuntansi (PSAK) No } \\
\text { Statement of Accounting Standards (SFAS) No. }\end{array}$} & \multirow[t]{2}{*}{ Keywords } \\
\hline & 10 & 13 & 16 & 22 & 23 & 24 & 30 & 48 & $\begin{array}{c}50 / 5 \\
5\end{array}$ & 58 & \\
\hline Nilai & & & & & & $\sqrt{ }$ & & & $\sqrt{ }$ & & Value \\
\hline Jumlah & $\sqrt{ }$ & $\sqrt{ }$ & $\sqrt{ }$ & $\sqrt{ }$ & $\sqrt{ }$ & & $\sqrt{ }$ & $\sqrt{ }$ & & $\sqrt{ }$ & Amount \\
\hline Suatu Aset Dapat Dipertukarkan & & $\sqrt{ }$ & $\sqrt{ }$ & $\sqrt{ }$ & & $\sqrt{ }$ & & & $\sqrt{ }$ & & An asset can be exchanged \\
\hline Suatu Aset dipertukarkan & & & & & & & & & & $\sqrt{ }$ & An asset is exchanged \\
\hline Suatu aset mungkin ditukar & & & & & $\sqrt{ }$ & & & & & & An asset may be exchanged \\
\hline $\begin{array}{l}\text { Dipergunakan untuk } \\
\text { mempertukarkan aset }\end{array}$ & $\sqrt{ }$ & & & & & & $\sqrt{ }$ & & & & Used to exchange assets \\
\hline $\begin{array}{l}\text { Dapat dipergunakan untuk } \\
\text { mengukur }\end{array}$ & & $\sqrt{ }$ & & & & & & & & & Can be used to measure \\
\hline $\begin{array}{l}\text { Dapat dihasilkan dari penjualan } \\
\text { suatu aset }\end{array}$ & & & & & & & & $\sqrt{ }$ & & & $\begin{array}{l}\text { Can be generated from the sale } \\
\text { of an asset }\end{array}$ \\
\hline Unit penghasil kas & & & & & & & & $\sqrt{ }$ & & & Cash-generating unit \\
\hline Suatu kewajiban diselesaikan & & & & & $\sqrt{ }$ & $\sqrt{ }$ & & & $\sqrt{ }$ & & An obligation is settled \\
\hline Suatu liabilitas diselesaikan & $\sqrt{ }$ & & & $\sqrt{ }$ & & & & & & $\sqrt{ }$ & A liability is settled \\
\hline Menyelesaikan kewajiban & & & & & & & $\sqrt{ }$ & & & & Settle the obligation \\
\hline $\begin{array}{l}\text { Antara pihak yang memahami } \\
\text { dan berkeinginan }\end{array}$ & & & & & & $\sqrt{ }$ & & & $\sqrt{ }$ & & $\begin{array}{l}\text { Between knowledgeable and } \\
\text { willing parties }\end{array}$ \\
\hline $\begin{array}{l}\text { Antar pihak yang paham dan } \\
\text { berkeinginan }\end{array}$ & & & & & & & & & & $\sqrt{ }$ & $\begin{array}{l}\text { Between willing and } \\
\text { understand parties }\end{array}$ \\
\hline Antar pihak yang berkeinginan & $\sqrt{ }$ & & & & & & & & & & Between willing parties \\
\hline $\begin{array}{l}\text { Antara pihak yang mengerti dan } \\
\text { berkeinginan }\end{array}$ & & & & $\sqrt{ }$ & & & & & & & $\begin{array}{l}\text { Between willing and } \\
\text { comprehend parties }\end{array}$ \\
\hline $\begin{array}{l}\text { Antara pihak-pihak yang } \\
\text { berkeinginan dan memiliki } \\
\text { pengetahuan memadai }\end{array}$ & & $\sqrt{ }$ & & & & & $\sqrt{ }$ & $\sqrt{ }$ & & & $\begin{array}{l}\text { Between willing parties and has } \\
\text { adequate knowledge }\end{array}$ \\
\hline Antara pihak yang memahami & & & & & $\sqrt{ }$ & & & & & & Between knowledgeable parties \\
\hline Suatu Transaksi Wajar & $\sqrt{ }$ & $\sqrt{ }$ & $\sqrt{ }$ & $\sqrt{ }$ & $\sqrt{ }$ & $\sqrt{ }$ & $\sqrt{ }$ & $\sqrt{ }$ & $\sqrt{ }$ & $\sqrt{ }$ & A fair transaction \\
\hline
\end{tabular}

Gambar 1 Konsep nilai wajar

\section{Penghitungan/Pengukuran Nilai Wajar tanpa Pasar Aktif}

Masalah mendasar dengan penggunaan nilai wajar atau nilai sekarang untuk instrumen keuangan khususnya adalah adalah sulitnya menentukan konsep nilai sekarang yang tepat untuk menilai suatu aset (nilai dimana suatu aset dapat dipertukarkan) dan liabilitas (suatu kewajiban dapat diselesaikan antara pihak yang memahami dan berkeinginan untuk melakukan transaksi wajar). Menurut Ikatan Akuntan Indonesia, keberadaan suatu pasar yang tidak aktif, antara lain, diindikasikan oleh beberapa faktor seperti: (1) peningkatan yang signifikan selisih ask price dan bid price; (2) pihak yang melakukan bidding jumlahnya terlalu kecil; (3) adanya volatilitas harga pasar yang signifikan; (4) jumlah efek yang ditransaksikan relative kecil dibandingkan dengan jumlah efek yang beredar; dan (5) penurunan signifikan atas volume dan level aktifitas perdagangan. 
Disebutkan dalam IAI bahwa, ketika pasar tidak aktif maka entitas menggunakan teknik penilaian yang mencerminkan harga pasar kini. Oleh karena itu, harga transaksi instrument keuangan yang sama atau serupa harus dipertimbangkan, jika harga transaksi kini kemungkinan besar mencerminkan kondisi pasar kini. Harga transaksi yang semacam itu harus dipertimbangkan, tetapi tidak secara otomatis dapat disimpulkan bahwa setiap harga transaksi bersifat determinatif atas nilai wajar. Jika harga transaksi semacam itu digunakan, maka diperlukan penyesuaian yang signifikan berdasarkan data yang tidak dapat diobservasi.

Penentuan nilai wajar tergantung pada fakta dan keadaan dan memerlukan pertimbangan signifikan. Terlepas dari teknik penilaian yang digunakan, entitas harus memasukkan penyesuaian resiko yang sesuai yang pelaku pasar akan lakukan, misalnya untuk kredit dan likuiditas. Ketika mengukur nilai wajar dengan menggunakan teknik penilaian, maka entitas memilih model penilaian yang paling relevan untuk digunakan, membuat asumsi-asumsi yang diperlukan dan menilai keandalan yang dapat digunakan atas informasi harga yang tersedia untuk maksud estimasi harga dimana transaksi yang wajar terjadi antar pelaku pasar pada tanggal pengukuran. Terlepas dari teknik penilaian yang digunakan, entitas memasukkan penyesuaian resiko yang sesuai dengan perilaku pelaku pasar.

Berikut adalah teknik penilaian menurut Diewert (2002). Disebutkan terdapat 7 metode pendekatan dan teori yang bisa digunakan untuk dasar penilaian aset, 5 di antaranya yang terkait dengan alternatif penghitungan nilai wajar selain dari historical valuation.

\section{Biaya Historis yang Disesuaikan dengan Tingkat Daya Beli (Purchasing Power Adjusted Historical Costing)}

Metode ini menggambarkan pembentukan nilai sekarang dari aset yang dimiliki oleh perusahaan dengan menyesuaikan harga perolehan menggunakan tingkat harga umum (general price level). Tingkat harga umum biasa disebut juga dengan tingkat inflasi umum. Metode pembentukan nilai sekarang (nilai pasar wajar) pada akhir periode akuntansi bekerja sebagai berikut misalkan sebuah aset dibeli pada awal periode akuntansi pada harga P0 dan Keuntungan dari penggunaan metode ini dalam rangka menentukan nilai aset saat ini dengan basis periode ke periode adalah sifatnya yang relatif sederhana (simple), yaitu nilai historis awal akan disesuaikan dengan tingkat inflasi umum.

Kelemahan utama dari penggunaan metode ini adalah dalam penentuan indeks harga umum. Dalam hal ini nilai pasar wajar dari aset tidak akan sama dengan nilai yang disesuaikan melalui indeks harga umum kecuali jika indeks inflasi atas aset tersebut sama dengan indeks inflasi harga secara umum. Salah satu alternatif paling sederhana dalam penentuan indeks pada metode ini adalah dengan menggunakan tingkat inflasi untuk komoditas yang diperjualbelikan secara luas (misalnya emas) sebagai indeks inflasi umum. Alternatif lain adalah dengan menggunakan tingkat kenaikan dari nilai tukar mata uang suatu negara dibandingkan dengan mata uang yang stabil. Hanya saja inflasi umum antara akhir periode dengan awal periode akuntansi dapat dilihat dengan lebih baik apabila digunakan perubahan harga atas gabungan barang-barang (indeks gabungan). Walapun mungkin penentuan indeks dalam dalam metode ini terkesan banyak kekurangan tetapi penyesuaian biaya historis dengan indeks harga umum akan lebih mencerminkan nilai saat ini daripada nilai historis murni.

\section{Nilai Realisasi Bersih atau Nilai Keluaran (Net Realizable Values or Exit Values)}

Menurut Edwards dan Bell (1961), exit value atau nilai keluaran adalah harga maksimum dari aset yang saat ini ditahan apabila dijual dan dikurangi dengan biaya transaksi. Dengan sebutan lain nilai keluaran disebut juga dengan nilai realisasi bersih (net relizable value) dari aset. Terdapat beberapa kritik yang dilakukan menyangkut penggunaan nilai realisasi bersih. Terutama adalah nilai ini mempunyai kelemahan dalam segi objektivitas. Maksudnya penentuan harga jual atas aset yang 
sebenarnya tidak ditujukan untuk dijual akan menimbulkan kesulitan karena dua penilai yang berbeda sangat mungkin membuat hasil yang berbeda dalam penerapan net realizable value. Selain itu entitas yang tidak memiliki pengetahuan pasar yang mencukupi tentang penjualan aset (karena memang bukan bidangnya) tentu akan kesulitan menentukan nilai yang lebih tepat.

\section{Biaya Penggantian Kembali atau Nilai Masukan (Replacement Costs or Entry Values)}

Yang dimaksud dengan replacement cost atau entry value adalah "Biaya penggantian kembali adalah jumlah uang yang harus dibebankan pada saat ini untuk memproduksi kembali properti fisik yang sama dengan yang ada saat ini” (Hayes, 1913, hal. 618). Replacement cost biasanya akan bernilai lebih tinggi dibandingkan dengan net realizable value karena dalam net relizable value nilai tersebut harus dikurangi dengan biaya transaksi.

\section{Aliran Kas Masa Depan yang Didiskonto (Future Discounted Cash Flows)}

Sebuah aset dimiliki perusahaan dengan tujuan untuk memberikan manfaat ekonomis bagi perusahaan. Aset tetap yang dimiliki perusahaan untuk lebih dari satu periode berarti diharapkan untuk bisa memberikan aliran manfaat ekonomis juga untuk lebih dari satu periode. Penentuan nilai untuk aset tersebut bisa dilakukan dengan menjumlahkan seluruh nilai kemampuan ekonomis yang mungkin dihasilkan oleh aset tersebut.

Cara perhitungan yang dilakukan adalah dengan membuat estimasi tentang penghasilan yang akan diterima dari beroperasinya aset tersebut. Kemudian menjumlahkan nilai yang diperoleh dengan mempertimbangkan tingkat diskonto. Didapatkan nilai sekarang dari aset yang bersangkutan. Kelemahan dalam penggunaan metode ini adalah dalam penentuan estimasi arus kas masa depan yang akan diterima oleh perusahaan. selain itu pendapatan yang diterima perusahaan merupakan hasil kerja bersama sekelompok aset yang dimiliki oleh perusahaan, dan akan sulit untuk menentukan proporsi nilai yang diperoleh ke dalam masing-masing aset secara tepat.

\section{Harga Tertentu (Specific Price Level Adjusted Historical Cost)}

Metode ini menggambarkan pembentukan nilai sekarang dari aset yang dimiliki oleh perusahaan dengan menyesuaikan harga perolehan menggunakan tingkat harga khusus (special price level). Tingkat harga khusus merupakan tingkat inflasi individu untuk jenis barang tertentu (dalam hal ini berarti aset tetap tertentu). Keuntungan dari penggunaan metode ini dalam rangka menentukan nilai aset saat ini adalah selain sifatnya yang sederhana juga lebih dapat menunjukkan nilai sekarang dari sebuah aset tetap tertentu.

Kelima contoh penentuan nilai wajar tersebut, tidak dapat dikatakan model mana yang paling baik dalam menentukan nilai wajar. Masing-masing model tersebut memiliki karakteristik tersendiri. Yaitu tergantung kepada kondisi dan data-data yang diperoleh oleh penilai serta jenis dari aset tetap yang akan dinilai kembali. Sebagai contoh untuk aset tetap yang digunakan untuk produksi perusahaan, model arus kas mungkin lebih cocok karena arus kas yang dapat dihasilkan oleh aset tetap tersebut lebih dapat ditentukan. Sedangkan untuk aset tetap lain yang tidak ditujukan langsung untuk proses produksi seperti tanah, nilai aset tetap tersebut mungkin tidak cocok jika ditentukan dengan metode arus kas. Model yang lebih cocok untuk penentuan kembali nilai pasar wajar dari aset tetap berupa tanah misalnya adalah model nilai realisasi bersih (exit value), yaitu nilai yang didapat jika tanah tersebut dijual. 


\section{Implementasi Nilai Wajar di Indonesia}

Kehadiran nilai wajar dalam dunia bisnis Indonesia pada umumnya dan dunia akuntansi pada khususnya, menimbulkan pro dan kontra di antara pelaku bisnis lokal, namun suka atau tidak, konsep ini harus kita terima dengan baik. Berbeda halnya dengan Amerika Serikat yang bersikap secara perlahan menerapkan fair value measurement yang telah diatur dengan sangat kompleks, detail, rinci oleh GAAP. Indonesia begitu mengetahui pasar sedang bergejolak dan kondisi di dalam negeri juga belum siap benar, Indonesia lebih memilih menunda penerapan nilai wajar. Indonesia akhirnya baru menerapkan nilai wajar secara penuh pada 2012.

Masalah ketidaksiapan Indonesia juga diakui Jusuf Wibisana. Menurut mantan Ketua DSAK tersebut, DSAK (Dewan Standar Akuntansi Keuangan) memang belum pernah melakukan penelitian tentang kesiapan Indonesia dalam menerapkan nilai wajar. Namun, diakui Jusuf, ada beberapa pihak atau bidang yang sudah siap, tapi banyak juga yang belum siap. Namun demikian, DSAK sudah menyusun beberapa standar yang semua mengacu pada IFRS/IAS, termasuk didalamnya konsep nilai wajar. DSAK juga menerbitkan buletin teknis sebagai panduan untuk melakukan perhitungan nilai wajar pada standar-standar tersebut. Hampir seluruh Pronouncement the International Accounting Standard Board sudah menerapkan dasar nilai wajar, Indonesia juga akan mengadopsinya.

Badan Pengawas Pasar Modal dan Lembaga Keuangan (BAPEPAM-LK) dalam beberapa peraturannya juga telah mengadopsi atau memasukkan konsep nilai wajar sebagai upaya mengikuti dan mendukung penerapan nilai wajar oleh DSAK, diantaranya IX.E.I tentang Transaksi afiliasi dan Benturan Kepentingan Transaksi Tertentu, IX.E.2. tentang Transaksi Material dan Perubahan Kegiatan Usaha Utama, IX.G.I tentang penggabungan usaha atau peleburan usaha perusahaan publik/emiten, IX.L.I. tentang Tata cara Pelaksanaan Kuasi Reorganisasi dan IV.C.2. tentang Nilai Pasar wajar dari efek dalam portofolio reksadana.

Pelaku dunia usaha sendiri, banyak yang belum siap dengan nilai wajar. Mereka belum siap untuk terbuka dan transparan bagi pihak lain atau investor yang ingin melihat isi perusahaan mereka. Disamping itu, pemerintah atau regulator juga belum benar-benar siap dengan paket-paket regulasi yang menjamin adanya keterbukaan informasi pasar. Salah satu sektor yang belum siap menerapkan nilai wajar adalah perbankan. Perbankan saat ini belum siap seluruhnya menerapkan nilai wajar. Karena itulah, PSAK 50 dan PSAK 55 tentang Instrumen Keuangan yang sedianya diberlakukan beberapa tahun lalu telah diundur beberapa kali pelaksanaannya. Sebagai gantinya, Bank Indonesia (BI) memberlakukan Pedoman Akuntansi Perbankan Indonesia (PAPI). Dibanding sektor lain, penerapan nilai wajar di matanya tergolong paling rumit dan kompleks. Sebab tak semua instrumen keuangan atau aset bank diperdagangkan di pasar modal.

Semua pihak terkait harus menyiapkan berbagai langkah penerapan nilai wajar tersebut. Semua PSAK yang diterbitkan DSAK tersebut nantinya harus dijadikan pedoman dalam menyusun laporan keuangan berbasis nilai wajar. Setelah 2012, apabila perusahaan atau entitas yang menggunakan laporan keuangannnya masih tidak menggunakan nilai wajar, oleh auditor akan diberi opini tidak bersih. Opini itu akan menurunkan tingkat kepercayaan publik. Karena itu, baik regulator, pelaku usaha, maupun pihak-pihak terkait harus bersama-sama melakukan upaya-upaya serius agar penerapan nilai wajar sesuai harapan. Meskipun secara penuh baru akan menerapkan IFRS di tahun 2012, dalam beberapa kasus atau entitas konsep nilai wajar ini di Indonesia sudah diterapkan. Saham yang diperdagangkan di pasar modal, misalnya dengan sendirinya penilaian sudah menggunakan nilai wajar. Komitmen Indonesia untuk menerapkan konsep nilai wajar dalam waktu dekat perlu disikapi dengan hati-hati, banyak kalangan mengingatkan untuk memperhitungkan untung rugi atau risikorisiko yang ditimbulkannya. Nilai wajar akan menguntungkan pelaku pasar atau investor karena memang mencerminkan nilai pasar yang sebenarnya. "Sebab informasi pasarnya terkini. Hanya, memang, kita akan kesulitan untuk menilai pasar yang tidak aktif. Dan untuk itu diperlukan penilaian model. 
Dibanding nilai buku/harga perolehan, nilai wajar memiliki tiga keunggulan, yaitu: (1) laporan keuangan menjadi lebih relevan untuk dasar pengambilan keputusan; (2) meningkatkan keterbandingan laporan keuangan; (3) informasi lebih dekat dengan apa yang diinginkan oleh pemakai laporan keuangan.

Penetapan nilai wajar dengan pedekatan harga pasar dapat memprediksi laba/rugi sebuah perusahaan, jauh jauh hari sudah bisa diprediksikan. Namun, penerapan nilai wajar ini akan menghadapi kendala-kendala yang cukup rumit. Sebagai contoh, untuk penentuan apakah suatu pasar itu aktif atau tidak aktif adalah persoalan krusial dan tidak mudah. Selain itu, pasar mungkin aktif untuk instrumen tertentu, dan tidak aktif untuk instrumen lainnya, dan ini juga tergolong hal yang sulit. Catatan lain lagi adalah, keberadaan willing sellers dan willing buyers kadang tidak cukup untuk menjustifikasi apakah suatu pasar terbilang aktif. Dan, harga yang terbentuk dalam forced transaction, forced liquidation, atau distressed sales mungkin tidak mencerminkan nilai wajar yang sebenarnya.

Secara umum, penerapan nilai wajar akan menguntungkan perekonomian Indonesia. Sebab, jika tidak dilakukan penilaian dengan nilai wajar, aset-aset perekonomian nasional, baik yang dimiliki swasta maupun pemerintah, selama ini dinilai terlalu rendah, jauh lebih rendah dari nilai sewajarnya. Misalnya aset-aset perusahaan perkebunan yang hingga saat ini masih menggunakan nilai buku. Sebagai gambaran, sebelum 1997, kebun sawit seluas satu hektare, misalnya cukup dibangun dengan uang Rp 12 juta atau hanya Rp 6 juta sebelum tahun 1990-an. Setelah terjadi krisis moneter 1998/1998, ketika harga dolar AS sudah naik tiga kali, untuk hal yang sama dibutuhkan biaya sampai Rp 30 juta. Sehingga, orang baru membuka perusahaan perkebunan, nilai bukunya sudah diatas Rp 25 juta semua. Padahal, penghasilannya sama dengan kebun-kebun lama yang lebih murah biayanya. Tapi nilai buku kebun lama kecil, dan hal Ini tidak menggambarkan nilai yang sebenarnya.

\section{Keunggulan dan Kelemahan Konsep Nilai Wajar}

Keunggulan menggunakan nilai wajar, yaitu memiliki sifat relevan, standar akuntansi nilai buku telah banyak kehilangan relevansinya karena kegagalannya mengukur realitas ekonomi. Hampir semua orang setuju bahwa peristiwa ekonomi, yaitu: kejadian yang mengubah waktu kapan arus kas diterima dan jumlahnya yang akan datang harus tercermin (terungkap) dalam laporan keuangan lembaga. Akan tetapi, seringkali model nilai buku hanya mengukur transaksi sudah selesai dan gagal mengakui adanya perubahan nilai riil lain yang dapat terjadi. Kemudian, dapat diandalkan (reliability), masalah yang selalu ada yang tidak dapat dihindari adalah bahwa model akuntansi berdasarkan historical cost tidak mengakui adanya perubahan nilai bersifat ekonomis, dan cenderung membiarkan perusahaan memilih sendiri apakah dan kapan mengakui adanya perubahan tersebut. Ini mendorong adanya bias dalam pemilihan apa yang dilaporkan, dan memperburuk kompromi kenetralan dan dipercayainya informasi keuangan.

Nilai wajar memiliki laporan keuangan lebih transparan, nilai wajar berusaha meningkatkan penyediaan informasi yang lebih transparan bagi semua pihak. Selain itu, nilai wajar meningkatkan keterbandingan (comparability), dengan penerapan konsep nilai wajar disemua perusahaan di dunia, maka semua laporan keuangan memiliki keterbandingan yang sangat tinggi dan akan menghasilkan keputusan-keputusan usaha yang lebih mendasar. Kekurangan nilai wajar adalah nilai wajar berusaha menyediakan informasi yang transparan dengan menilai aset pada tingkat harga yang dihasilkan jika segera dilikuidasi-sehingga sangat sensitif terhadap pasar.

Selain itu, akuntansi fair value bekerja melalui akuntansi mark-to-market (MTM), yaitu aset dicantumkan pada harga pasar mereka jika diperdagangkan secara terbuka. Menggunakan akuntansi mark-to-market akan berakibat perubahan yang terus-menerus pada laporan keuangan perusahaan ketika nilai aset mengalami kenaikan dan penurunan serta laba dan rugi yang dicatat. Hal ini membuat semakin sulit untuk memastikan apakah laba dan rugi diakibatkan oleh keputusan bisnis yang dibuat manajemen atau oleh perubahan yang terjadi di pasar. 
Nilai wajar bersifat volatility, lembaga keuangan mengatakan bahwa mereka takut akuntansi berdasarkan pasar akan menyebabkan volatility kinerja lembaga (karena semakin mudahnya nilai item-item aktiva dan pasiva berfluktuasi). Walaupun sebenarnya lembaga keuangan yang senantiasa mengelola bahaya yang mengancam aset dan liabilitas, hanya sedikit takut dengan market value accounting. Laporan keuangan lembaga keuangan yang kurang efektif dalam mengelola risiko akan tercermin pada volatility yang selalu ada dalam setiap usahanya. Para investor dan kreditur akan memiliki informasi yang lebih berguna dan relevan dalam membedakan risiko antar perusahaan, ketika mengambil keputusan investasi dan keputusan pemberian kredit (jika menggunakan MVA).

Fair value akan membuat perbedaan penilaian pihak manajemen perusahaan, sehingga kalau ada kontrol yang kurang baik akan memungkinkan peluang earning management. Adanya biaya tambahan yang ditanggung perusahaan dan kebutuhan sumber daya manusia (SDM). Biaya penerapan akuntansi nilai wajar berbeda untuk perusahaan yang berbeda. Hal-hal yang berpengaruh terhadap besaran biaya adalah, antara lain, jenis transaksi dan besaran akun yang ada di perusahaan, kompetensi dari SDM, kecanggihan teknologi informasi, program yang diinginkan, serta jumlah user yang harus memahami dan menerapkan akuntansi nilai wajar. Bila menggunakan konsultan, biaya konsultan juga harus diperhitungkan.

\section{Peranan Profesi Penilai (Appraisal) dalam Penerapan Nilai Wajar}

Penerapan Nilai Wajar dalam IFRS membuka peluang jasa appraisal (penilai) secara signifikan. Hambatan berupa kendala atas kesalahan penilaian sebuah aset dapat diminimalisir dengan pemakaian jasa appraisal. Tapi, perusahaan juga harus mempertimbangkan biaya dan manfaat, serta keputusan final hasil penilaian jasa apparaisal akan tergantung kebijakan manajemen. Peran dan fungsi profesi penilai akan semakin penting ketika di Indonesia diterapkan konsep nilai wajar. Namun, yang lebih penting lagi sebenarnya adalah kesiapan semua pihak terkait, mulai dari regulator, pelaku dunia usaha, akuntan, penilai, hingga masyarakat umum. Sebab, tanpa kesiapan semua pihak terkait, penerapan nilai wajar justru akan menjadi masalah baru.

Ketua Umum Pengurus Pusat Masyarakat Profesi Penilai Indonesia (MAPPI) atau Indonesian Society of Appraisers Hamid Yusuf, mengatakan bahwa nilai pasar dicatatkan sebagai fair value di dalam akuntansi. Penekanannya pada penilaian asset tetap (property fixed). Untuk penilaian penilaian yang lainnya, untuk kepentingan akuisisi, investasi, MAPPI juga memberlakukan nilai wajar.

Penilai, sebagai satu profesi, merupakan orang yang dianggap kompeten memberikan opini nilai yang kebetulan di disitu dibutuhkan untuk kepentingan keuangan/akuntansi. Maka, penilai menyesuaikan apa yang diinginkan oleh laporan keuangan itu. Sebenarnya, penilaian pada awalnya dilakukan untuk agunan. Karena, pada awalnya penilaian memang lebih banyak digunakan untuk menilai agunan. Itu bisa berbeda kalau tujuannya untuk laporan keuangan Untuk kepentingan laporan keuangan, sebenarnya, di sana ada asset berupa tanah dan bangunan yang tujuannya bukan untuk dijual, tapi untuk diteruskan penggunaannya secara operasional sebagai bagian usahanya. Misalnya, kantor sebagai aset operasional, maka dicatatkan sebagai aset tetap di dalam neraca. Aset tetap itulah yang diatur dalam PSAK 16. Di IFRS namanya property plant and equipment.

Jadi, penilai mencoba memahami bagaimana akuntan membutuhkan itu, kemudian diwujudkan dalam bentuk metode, dalam bentuk jenis nilai, dan seterusnya. Tapi, kalau tujuannya untuk listing lain lagi. Kalau tujuannya untuk merger atau akuisisi, bisa beda lagi. Intinya, penilai itu adalah orang yang memang dianggap profesional untuk melakukan pekerjaan penilaian itu. Meningkatnya kebutuhan akan profesional dibidang penilaian, akan menimbulkan kelangkaan yang berakibat kurang baik, seperti bajak membajak ahli jasa penilai, sehingga perlu mulai sekarang direncanakan kemudahan dan fasilitas pendidikan serta sertifikasi yang memungkinkan diperolehnya tenaga-tenaga yang ahli dibidang jasa penilai yang sebelum nya dianggap merupakan profesi yang kurang diminati. 


\section{Implikasi Nilai Wajar pada Dunia Usaha}

Dalam penilaian asset dan liabilitas, secara konvensional ada tiga metode atau hierarki yang juga sudah disesuaikan dengan standar akuntansi. Pertama menggunakan pendekatan pasar. Yang digunakan adalah harga pasar. Pendekatan yang mengambil langsung pembandingnya dari asset atau liabilitas sejenis yang nilainya ada di pasar. misalnya, menilai ruko, langsung kita cari berapa pasaran ruko itu. Ini apple to apple, dan di akuntansi juga diatur masalah ini. Itu namanya pendekatan pasar. Kalau tidak ada yang persis sama, misalnya tuan A punya rumah tipe 125, dan tuan B punya rumah tipe 125, tapi tuan A tinggal di Jakarta dan tuan B tinggal di Bandung, kan belum tentu sama nilainya. Atau, sama-sama di Jakarta jika berbeda spesifikasi, tentu nilainya juga akan beda. Jika pembandingnya terbatas, maka menggunakan pendekatan kedua. Ini masih menggunakan pendekatan pasar, tapi mempertimbangkan nilai pendapatan. Misalnya perkantoran, karena dia menghasilkan pendapatan, maka metodenya menggunakan pendekatan pendapatan. Kalau tidak, menggunakan pendekatan ketiga, yang disebut dengan depreciated replacement cost atau biaya pengganti terdepresiasi, biasa disebut pendekatan biaya.

Definisi nilai wajar dalam IAS/IFRS secara substansial dinyatakan secara konsisten, sedangkan di Indonesia dari seluruh PSAK yang berlaku saat ini hanya 11 PSAK yang menyatakan menggunakan nilai wajar, dan hanya PSAK 50, 55 dan 60 yang menyatakan nilai wajar yang identik, sedangkan sisa kesembilan PSAK lainnya, tidak memuat definisi nilai wajar yang sama. Ketidakkonsistenan tersebut umumnya disebabkan oleh ketidak-konsistenan penerjemahannya.

Metode penentuan nilai wajar dalam PSAK yang saat ini berlaku juga beragam dan tidak konsisten antara satu dengan lainnya. Kondisi tersebut tentu akan membingungkan para penyaji dan pemeriksa laporan keuangan, serta akan menimbulkan ketidak-seragaman implementasi PSAK berbasis IFRS. Sebagai akibat dari masalah tersebut,PSAK berbasis IFRS mungkin tidak bias menghasilkan laporan keuangan yang andal. Dengan ketidak-konsistenan tersebut dapat mengakibatkan tujuan utama IASB untuk menghasilkan standar tunggal berkualitas tinggi, mudah dimengerti, dapat dilaksanakan dan diterima secara global melalui IFRS belum tercapai. Seperti yang telah diuraikan, PSAK tidak memiliki metode penentuan nilai wajar yang konsisten. Beberapa PSAK memuat ketentuan tentang nilai wajar melalui tiga tahap, PSAK lainnya menggunakan dua tahap, dan yang lain tidak memberikan acuan metode penentuan nilai wajar. Gambar 2.

Metode penentuan nilai wajar dari masing-masing PSAK yang ada saat ini tertera dalam 


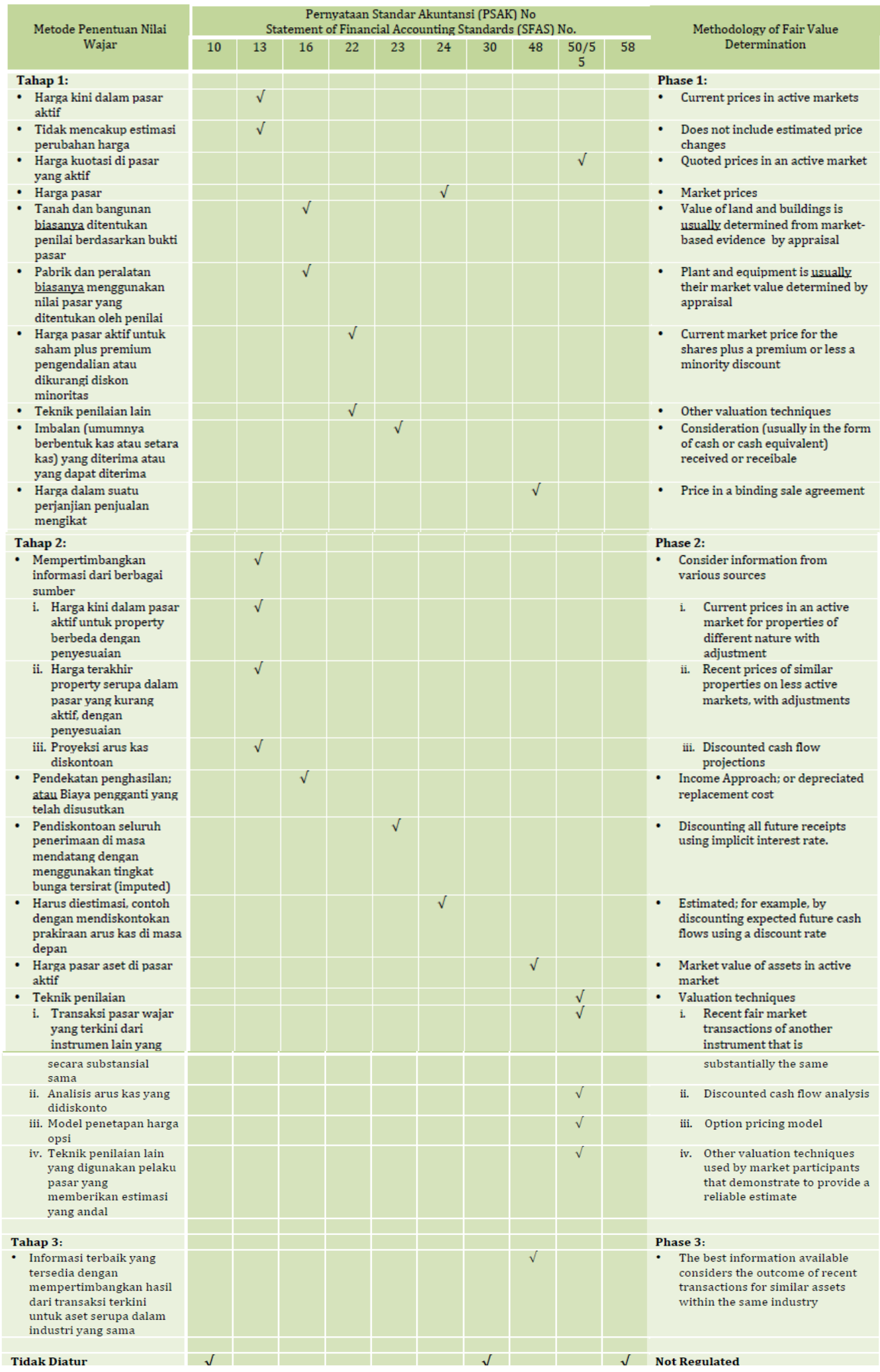

Gambar 2 Metode penentuan nilai wajar Sumber: Harto (2010) 


\section{PENUTUP}

Konsep nilai wajar (fair value) yang saat ini dianggap memiliki keunggulan dibandingkan dengan nilai buku (historical cost), merupakan konsep yang diberlakukan secara luas diseluruh dunia, suatu organisasi usaha yang ingin tumbuh dan berkembang menjadi perusahaan global, publik atau multinasional harus siap untuk menerapkan konsep nilai wajar dalam akuntansinya. Ada 5 hal yang perlu dilakukan oleh perusahaan dalam upaya beradaptasi dengan konsep nilai wajar ini, yaitu: (1) berusaha memahami dan mendalami konsep akuntansi nilai wajar; (2) perusahaan usaha menyiapkan analisa jarak (gap analysis) untuk memahami apa yang harus dilakukan untuk menutup gap antara praktek yang sekarang dengan yang harus dilakukan dalam penerapan nilai wajar; (3) perusahaan harus menyusun sistem informasi yang mengakomodasi standar-standar baru yang sudah menerapkan nilai wajar; (4) perusahaan memperbaiki sistem teknologi informasi untuk mengakomodasi permintaan dalam penerapan nilai wajar; dan (5) perusahaan melakukan uji coba dengan parrarel run sampai diperoleh keyakinan bahwa sistem yang baru siap untuk go live. Kelima hal ini harus mendapat dukungan penuh dari manajemen puncak dengan mempertimbangkan penggunaan jasa konsultan untuk membantu semua.

Upaya harmonisasi PSAK dengan IFRS untuk meningkatkan konsistensi dan daya banding serta keandalan laporan keuangan perlu dilakukan dengan cermat dan sungguh-sungguhnya khususnya dalam penentuan nilai wajar. Standar tunggal antara PSAK dengan IFRS tentang penentuan nilai wajar setidaknya memuat definisi dan metodologi tunggal serta petunjuk implementasi yang komprehensif dalam setiap situasi dan kasus yang berbeda. Dengan adanya standar tunggal dan komprehensif tersebut diharapkan dapat mengurangi kebingungan pelaku sehingga meningkatkan kualitas dan keandalan laporan keuangan. Sebuah standar yang baik biasanya memiliki metode pengukuran yang kandungan ketidak-pastiannya terukur, dalam hal ini PSAK tidak secara gamblang memuat prinsip pengukuran ketidak pastian dan rentang waktu, sehingga mungkin akan meningkatkan biaya penyajian laporan keuangan serta mengurangi kegunaan laporan keuangan. Aplikasi nilai wajar secara tunggal antara PSAK dengan IFRS dalam laporan keuangan perusahaan di dunia dan di Indonesia khususnya akan menghasilkan adanya laporan yang sama (one world one standard) diharapkan akan berdampak positip dalam peningkatan perekonomian global, dimana tidak ada keraguan dari investor dan pelaku pasar dalam menyalurkan investasi modal dan teknologi keseluruh Negara tanpa keraguan dan hambatan yang pada gilirannya akan meningkatkan kesejahteraan umat manusia.

\section{DAFTAR PUSTAKA}

Epstein, C. J., \& Jermakowicz, E. K. (2010). Interpretation and application of IFRS. John Wiley \& Sons

Harto, Y. B. S. (2010). Konsistensi metode penentuan nilai wajar dalam standar akuntansi keuangan berbasis international financial reporting standards. Diakses dari: http://www.arghajata.com/article/pdf/ajcpub016-1293812727.pdf

Ikatan Akuntan Indonesia. (n.d.). Standar akuntansi keuangan. Jakarta: Salemba Empat.

Ikatan Akuntan Indonesia. (2008). Penentuan nilai wajar instrumen keuangan ketika pasar tidak aktif. Buletin Teknis, 3.

Shanklin, S. B., Hunter, D. R., \& Ehlen, C. R. (2011). A retrospective view of the IFRS: conceptual path and treatment of fair value measurements in financial reporting. Journal of Business \& Economics Research, 9(3), 23-29. 